\title{
History and Evolution of the Environmental Management System in Brazil ${ }^{1}$
}

\author{
Valdir Fernandes ${ }^{2}$, Cleverson Vitorio Andreoli ${ }^{3}$, Gilda Collet Bruna ${ }^{4}$, Arlindo Philippi Jr $^{5}$
}

\begin{abstract}
The idea of sustainable development emerges first as a socio-political movement, from a series of questions and concerns that have arisen at the international level, related to the contamination of natural environments and human beings, a result of industrial activities. From these concerns, a series of events and movements caused significant changes in international and national policies, leading to the construction of a significant legal framework and institutional apparatus, never seen in any other theme. The establishment of environmental management systems in most countries was a direct reflection of an international agenda launched during the Stockholm Conference, in 1972, which was continued with several other conferences and protocols, such as Rio-92, Rio+20, Kyoto Protocol, Paris Agreement, among others, that have consolidated an international environmental agenda over the past 50 years. In Brazil, this process generated direct reflexes with the construction of a significant legal framework and institutional apparatus. In this article, we describe this process, an important part of both the world's and the Brazilian environmental history until 2014.
\end{abstract}

Keywords: Sustainable Development; Environmental Public Policies, Brasilian Environmental System; Environmental History.

\footnotetext{
${ }^{1}$ Text originally published in Portuguese in: Philippi Jr, Arlindo. Andreoli, Cleverson Vitório. Bruna, Gilda Collet. Fernandes, Valdir. 2014. Histórico e Evolução do Sistema de Gestão Ambiental no Brasil. In: Arlindo Philippi Jr; Marcelo de Andrade Roméro; Gilda Collet Bruna. (Org.). Curso de Gestão Ambiental. 2ed. Barueri: Manole, v. 1, p. 19-52.

${ }^{2} \mathrm{PhD}$ in environmental engineering (Federal University of Santa Catarina). Full Professor at Federal University of Technology - Paraná / Brazil (UTFPR), ORCID: https://orcid.org/0000-0003-0568-2920, email: vfernandes @ utfpr.edu.br

$3 \mathrm{PhD}$ in Environment and Development (Federal University of Paraná). Professor at Mercosur Administration and Economy Institute (ISAE), ORCID: https://orcid.org/0000-0002-9486-1236, email cleverson@andreoliambiental.com.br

$4 \mathrm{PhD}$ in architecture (University of São Paulo - USP). Associate Professor at Universidade Presbiteriana Mackenzie, ORCID: https://orcid.org/0000-0001-5242-6714, email gildacbruna@gmail.com

5 PhD in public health (University of São Paulo - USP). Full Professor at University of São Paulo (USP), ORCID: https://orcid.org/0000-0003-04207749, email aphij@usp.br
} 
he intrinsic complexity and scope of environmental issues are naturally reproduced in management processes. Reflection on the evolution of the

National Environment System is an important part of the task of understanding the legal, institutional, technical, and operational structures with a view to the country's development on a sustainable basis.

Public policies must not only improve preservation and control, but also evolve in stimulating actions that lead to sustainability. Difficulties in Brazilian public management resulting from the structure, lack of competence, regulations, and excessively bureaucratic processes compromise the effectiveness of state action and hinder the process of policy appropriation in the business and social sectors.

By revisiting the evolution of environmental management systems in a broad sense, the objective of the present article is to describe the trajectory of insertion of the environmental issue in the Brazilian political and institutional scenario, considering the world historical context characterized by the interdependence of nations, and to suggest directions for progress environmental management in the country.

This trajectory, with its advances and difficulties, is approached based on historical landmarks, the evolution of environmental systems in the world, and international conferences and their institutional and legal reflexes in Brazil, since its genesis in the 1950s, its first steps in the 1970s, until 2014, a period of intense formalization of sustainability on the countries' agendas, with legislation, agreements, treaties, etc.

\section{HISTORICAL LANDMARKS}

A significant milestone that deserves to be highlighted in the constitution of environmental systems is the creation of the World Health Organization (WHO), proposed in 1946 and consolidated in the first World Health Assembly, in 1948. The creation of the WHO was motivated by a series of questions and concerns that arose at the international level, related to the health situation in national states. 
The contamination of natural environments and humans, resulting from industrial activities, drew the attention of the scientific community. Among the classic reports in the literature, the following stand out: smog, a type of air pollution that occurred in London in 1952, which killed about 4,000 people and caused the British government to enact the first Clean Air Act, in 1956; and cadmium and mercury poisoning in the Minamata and Niigata Bays, in Japan, and their effects on the health of the region's inhabitants, with the occurrence of diseases registered since 1956.

The publication of the book Silent Spring by the American Raquel Carson, in $1962^{6}$, played an important role in raising society's awareness of the risks and compromises of the quality of the environment and its effects on human health. The author, afflicted with cancer, reflects on the systematic disappearance of species of fauna due to the excessive use of insecticides based on DDT (Dichloro-DiphenylTrichloroethane), the probable cause of her disease. Carson addresses the biological magnification of chlorinated synthetic insecticide molecules by demonstrating that pesticides used in the recommended doses could be concentrated in the food chain, causing problems for organisms that occupy higher levels of the trophic scale, including humans. Raquel Carson completed her master's degree at Johns Hopkins University at the age of 24 and authored important works in the field of marine ecology. Her scientific credibility, coupled with her literary verve, made Silent Spring an international best-seller, causing a significant impact on American and world public opinion.

The increasingly frequent documentation of cases of pollution and contamination of environments affecting people encouraged scientists to develop their studies on the relation of causes and effects, and the publication of research results provoked strong reactions in society. In 1972, the report entitled Limits to Growt was published by a team from the Massachusetts Institute of Technology $\mathrm{MIT}^{7}$. This report was commissioned by the Club of Rome, a virtual institution formed by scientists, representatives of the political and industrial sector, from different institutions. The study created, with digital graphics, a novelty for the time, future 
scenarios of serious environmental problems considering the evolution of the pattern of population growth and consumption. The report received much criticism from currents that taxed this proposition of limit to growth as a neo-Malthusian view.

\section{EVOLUTION OF ENVIRONMENTAL MANAGEMENT SYSTEMS IN THE WORLD}

Concomitantly as a result of historical events and in response to the environmental problems that were evident, some countries, especially the wealthier ones, started to develop their environmental systems. The United States, during the Roosevelt period, in the 1920s, with a conservationist vision, encouraged the increase in the number of National Parks and Forest Preservation Areas. At that time, issues related to water pollution and remediation were the responsibility of the public health area. These two elements were significant in the creation of bases for the US National Environmental Policy Act, in 1969, leading to the creation of the US Environmental Protection Agency - USEPA, in 1970.

In Canada, concerns about the environmental issue, evidenced in the late 1960s, resulted in the creation of Environment Canada - EC, in 1972, a body that formulates and executes policies related to environmental issues. In 1985, Canada created its Ministry of Environment. In 1988, the meeting of the sparse laws on the subject constituted the Canadian Environmental Protection Act - CEPA, reformulated and expanded in 1999.

In the European context, Germany stands out initially. The German Constitution of 1949 already contemplated aspects related to the environmental issue, which gain greater emphasis in the Constitution of 1994. In 1974, the German Federal Government created its Environmental Protection Agency, which, in the exercise of its institutional powers, indicated the need to create other agents and sectors in the country for the gradual incorporation into the system. Thus, in 1986, the Ministry of the Environment, Nature Conservation and Nuclear Safety was created; in 1989, the German Office for the Protection of Radiation; and, in 1993, the Federal Nature Conservation Agency. In 2002, Germany builds strategies and defines actions for 
sustainable development, published in the document Perspectives for Germany 2002.

Great Britain started environmental actions in the late 1960s, but it was only in 1985 that it created the Department for the Environment, expanded in 1997 to Environment and Food, which in 2001 changed to the Department for Environment, Food \& Rural Affairs ${ }^{8}$.

Sweden played an important role in relation to environmental issues, with emphasis on the creation of the first Environmental Control Agency in the world, the Swedish Environmental Protection Agency, in 1967. The existence of this political and administrative body has allowed for several advances in the environmental area. Questions raised by the Swedish national agency were brought, in conjunction with the United States Environmental Protection Agency, to the Stockholm Conference in 1972. In 1986, Sweden created the Ministry of the Environment and, in 1999, its Environmental Code was promulgated, integrating 15 laws that dealt with the central issues of the area.

The strategy of environmental management with hydrographic basins as territorial units, implemented by the French water law of 12 December 1964, created the financial agencies of the basin, with the objective of promoting the integrated management of the use of water resources and other environmental resources of a hydrographic basin. The French system had a great influence on Law No. 9.433, of January 8, 1997, which instituted the National Water Resources Policy in Brazil and created the National Water Resources Management System, constituted, among others, by the National Water Agency (ANA), in addition to specific public structures in most Brazilian states. This system is based on user-payer financing and provides for the implementation of national and state water resources councils, composed of representatives of the state, users, and civil organizations.

The evolution of environmental management systems continued with the creation of the European Union. This political unit brought together several countries, each with responsibility and experience in organizing and coordinating actions in 
favor of environmental protection and control in their territory. In this context, the Directorate-General for Environment, based in Brussels, was created with the responsibility of establishing resolutions and common actions for member countries.

In Asia, Japan stands out, driven mainly by the heavy industrialization that occurred in the post-war period. Concerns about environmental issues arose in the 1960s, with the Air Pollution Control Act, in 1967, and the Nature Conservation Law, in 1972. These laws were precursors to the current National Environmental Law, instituted in 1993. The Japanese Environment Agency was created in 1971. In addition, the various laws dealing with environmental issues were incorporated into Japanese legislationin in 1993, and a sustainable development plan was created in 1994, called the Basic Environment Plan. In 2001, the Japanese Ministry of the Environment had its activities reviewed and expanded, placing strong proposals and, mainly, support and incentives for the development of the local Agenda 21.

\section{INTERNATIONAL CONFERENCES, AND INSTITUTIONAL AND LEGAL REFLECTIONS IN BRAZIL}

Considering the several historical milestones related to topics of environmental interest and the publication of the "Limits to Growth" Report, many Conferences were organized, which started to discuss the environmental issue. The UN Conference on the Human Environment, proposed by the so-called developed countries, held in Stockholm in 1972, shares deep links with the discussions brought up in this Report. This first international event counted with a significant participation of countries, pointing out the emerging need to discuss issues associated with environmental problems and their impacts on populations, including the issue of environmental education as a fundamental condition to think about reversing ongoing degradation processes. At this Conference, UNEP was created. The consolidation of the concept "ecodevelopment", which in the following years was considered characteristic of an extreme environmental model, giving rise to the construction of the new terminology "sustainable development", which would be considered a more "conciliatory" proposal. The first UNEP texts that linked environmental problems to 
the development model practiced by the main economically developed nations on the planet were politically frowned upon, mainly by the American government, despite the important advances promoted by the United States Environmental Protection Agency (USEPA).

As a consequence of the movement triggered at the Stockholm Conference, other meetings were held addressing aspects associated with the themes dealt with in there. Among these aspects, the issue of human settlements and the existence of excessively accelerated urbanization processes, discussed at the 1976 Habitat I conference in Vancouver, which led to the creation of a United Nations center for studies related to urban development in British Columbia University; and the issue of environmental education addressed in Tbilisi, which brought together elements previously worked on in Belgrade, at the first Intergovernmental Conference on Environmental Education in 1977. In addition to these two aspects, health-related issues were also the subject of a Conference on Health Promotion, held in Ottawa in 1986, in which, as conditions for the existence of health, elements related to work, the environment, land tenure and use, and income-related conditions, among others.

As a result of these international movements, influences were exercised in the countries, producing institutional reflexes and national policies, even in the end of the 1960s, 1970s and 1980s. In Brazil, some of these reflexes are worth highlighting, such as the creation, of FUNDACENTRO in 1968, with the objective of carrying out studies, research, and training of human resources to face problems identified in relation to safety, hygiene, and occupational medicine. Likewise, based on the discussions held at the conferences and from the identification of aspects that brought serious problems to Brazilian cities, with emphasis on water supply and sanitation, the National Sanitation Plan, then called PLANASA, was created. Some of its goals, which were quite ambitious, were achieved in the proposed period, mainly with regard to the water supply service. As for sewage, there was partial fulfillment of the established goals. Notwithstanding, there was a significant advance in the water collection, treatment and distribution systems, fulfilling in 1980 the planned goals in 1970. The sewage coverage, although expanded, was below expectations, with emphasis on the failure to meet the goals regarding sewage treatment. 
When at the United Nations Conference, in 1972, environmental problems were discussed, the position presented by the Brazilian representative was that the technologies that developed countries understood as obsolete and not appropriate for the industrial process could be accepted in Brazil. This position brought a series of unfavorable national manifestations, as well as negative reflexes in an international scope. This fact, associated with several environmental incidents and accidents, led the Brazilian government, through the Ministry of the Interior, to propose the creation of the Special Secretariat for the Environment (SEMA), as a governmental institution that would meet national environmental demands.

One of the factors that drove the structuring of the Brazilian federal environmental management system was international pressures in the wake of the Stockholm Conference, in 1972, and actions by financial development agencies such as the Inter-American Development Bank (IDB) and the World Bank. For large works financed with external resources, environmental studies were often required.

This external influence was responsible for the mimicry of the Brazilian environmental policy in relation to that practiced in developed countries. The focus of the National Environment System was the licensing of polluting activities (SLAP), as this was the environmental challenge at the time for developed countries. However, in the same period, the main Brazilian environmental problems were related to the management of natural resources, such as the expansion of the agricultural frontier over forested areas, disordered urban growth, mineral exploration, and the implementation of public transport and energy infrastructure. Pollution control itself was a marginal problem restricted to large urban and industrial centers, mainly in São Paulo State. Only years later did the licensing system evolve towards the design of the Environmental Licensing System (SLAM).

SEMA was created in 1973, the year in which the first movements were also observed in the Brazilian states regarding the creation of environmental agencies, an initiative of the federal government.

The first environmental agency in Latin America was the Intermunicipal Commission for the Control of Water and Air Pollution (CICPAA), which has operated in the municipalities of Santo André, São Bernardo do Campo, São Caetano do Sul and 
Mauá since August 1960, in the ABC region, Greater São Paulo. This body gave rise to CETESB, created in 1968, which incorporated the Superintendence of Environmental Sanitation (SUSAM), linked to the Secretariat of Health.

This example was an exception in the country, since the other state environmental agencies were created in the 1980s due to the encouragement by SEMA, following guidelines defined by Law 6.938/81, which provides for the National Environment Policy, its purposes and mechanisms of formulation and application, and makes other provisions. Several bodies were created from existing structures: the Department of the Environment (DMA), linked to the Public Health Secretariat of Rio Grande do Sul State; FATMA, in Santa Catarina State, linked to the extinct State Secretariat for Urban Development and Environment (SDM); the Superintendence of Water Resources and Environment (SURHEMA), in Paraná State, linked to the Secretariat of the Interior. Each state took advantage of the existing institutional structures to create bodies capable of carrying out the licensing of polluting activities (SLAP), which later evolved into the licensing of environmental activities (SLAM). During this period, the election of state governors took place, and later the first Civil President after the end of the military regime also did, which elected Tancredo Neves. These elections opened spaces for various democratic movements and for an atmosphere of "openness", from which the environmental dimension integrated government guidelines in several states and in the presidential campaign.

The structuring of environmental agencies took place in the 1980s, without funding from the federal government, when the global liquidity crisis arising from the oil crisis imposed restrictions on public expenditures in Brazil.

Gradually, the creation of these organizations impacted national policies. In 1979, with Federal Law 6.766/79, the so-called Lehmann Law, as amended by Law No. 9.785 of January 29, 1999, which amends Decree-Law No. 3.365 of June 21, 1941 (expropriation for public use) and Law No. 6.766 of December 19, 1979 (urban land division). The standardization of land division was formalized, incorporating those related to the discussions of HABITAT I, the first Conference on Human Settlement, held in Vancouver, Canada, in 1976. SEMA, supported by scientists, professors, researchers, and professionals from different areas and regions of Brazil, developed a 
proposal that served as the basis for the National Environment Policy, promulgated in 1981, by Federal Law 6.938/81. This policy created the National Environment System (SISNAMA).

Elaborated in the light of the most modern concepts of environmental management in force at the time, in general, the law was oriented to seek the sustainable development defined in its text as "the compatibility of socioeconomic development with environmental preservation", as stated in article 4, item I. Among the proposed management instruments were: the establishment of environmental quality standards, zoning, impact assessment, the guarantee of access to information, the implementation of economic instruments and the environmental quality report. However, some have not yet been implemented.

This law was received with great expectation, both internally and externally, as it was politically far ahead of its time. Both Law 6.938/81, which defined the Brazilian environmental policy and created SISNAMA, as well as the environmental legislation and especially the subsequent environmental regulations, were approved with a certain disbelief as to their effective application, or more because it was only later that the need for other laws to complement environmental control was identified. It was necessary to learn together with the State itself, which still ignored much of the environmental regulation; the environmental agencies had no political expression that would allow significant action, especially when it came to public works. In addition, its practical application was initially hampered by the difficulty of structuring environmental agencies, lacking the minimum resources needed for proper management, a situation that is still current in most states.

The national political framework underwent a major change with the Direct (Elections) Now (Diretas Já) movement, which, even though was not successful in obtaining a direct election for President of the Republic, led to the direct election of governors in 1982. Whereas the SEMA Secretary had been chosen by a nominated president, Conama's advisers and state representatives acted on behalf of democratically elected governments. In order to expand the political spaces to influence the national environmental policy, the Brazilian Association of Environmental Authorities (ABEMA) was created in 1985, a period still marked by the 
excessive concentration of attributions at the federal level. The initial objective was to strengthen the positions of the states in the national debate, which then had a progressive orientation towards the federal government, actively participating in the consolidation of environmental policy, consolidating the decentralization of executive activities of environmental management based on the current chapter of the Constitution in place at the time. The States also contributed technically to the CONAMA resolutions, mainly the Resolution 01/1986, which deals with guidelines for the implementation of the Environmental Impact Assessment as an important instrument of the National Environment Policy, Resolution 020/1986, which defined the parameters for the classification of rivers, and Resolution 237/97, on licensing local impact activities ${ }^{9}$.

An initiative of ABEMA, the first Brazilian Congress of Municipalities and the Environment was held in Curitiba, in 1986, with the objective of creating the National Association of Municipalities and the Environment (ANAMA). This institution encouraged the creation of Municipal Environment Departments in the main Brazilian cities to foster the municipalization of environmental management for activities with local impact. ABEMA was also responsible for the elaboration of a document, called "Brazil 92 - Environmental Profile and Strategies"10, which presented an environmental diagnosis of the different Brazilian regions, the evaluation of the environmental policy in the states, the indication of guidelines aiming at the evolution of environmental management systems in the country, and suggestions of international policies for sustainable development. This effort, which directly involved more than two thousand people linked to the environmental area, started with a state stage, which directly involved the community of all states in the country, was consolidated in regional seminars and, finally, in a national stage.

Another factor of fundamental importance in Brazilian environmental management was Law 7.347/85, known as the Law of Diffuse Interests. Diffuse interests are understood as those that do not belong to anyone in particular and at the same time to everyone, known as Transindividuals or Metaindividuals, such as the

\footnotetext{
${ }^{9}$ Associação Brasileira de Entidades Estaduais de Meio Ambiente, Abema, 2011. O que é Abema. Accessed on: Jun. 12, 2011. Available at: http://www.abema.org.br/site/pt-br/abema

10 São Paulo (Estado). Secretaria do Meio Ambiente - Brasil'92 Perfil Ambiental e Estratégias. 1992. São Paulo, Secretaria do Meio Ambiente, $218 p$.
} 
Right to the Environment, Consumer Rights, Right to Historical Values, among others. Based on this law, the action of the Public Prosecutor's Office assumes great influence on environmental management through the Public Civil Action, a procedural instrument used to suppress or, in a preventive manner, prevent any and all damage of a certain property of diffuse interest.

This action by the Public Prosecutor's Office was responsible for homogenizing compliance with environmental legislation, which was ignored or only partially applied in some Brazilian states. The more progressive business sector quickly understood that Brazil required another form of appropriation of natural resources. However, many are still reluctant to accept criteria established by environmental legislation, which define rules for the use of private property.

Currently, one of the greatest difficulties of the private sector is the lack of technical guidance for environmental management in enterprises, largely due to the complexity of the legislation in force. Environmental legislation, especially the regulation of Decrees, Resolutions and Ordinances give rise to several interpretations that result in great subjectivity for entrepreneurs, as it is not uncommon that, within the same environmental agency, different technicians have different understandings of the application of environmental legislation. This fact is aggravated when it comes to different spheres of government and the Public Prosecutor's Office. Clarification is needed regarding the interpretation of laws and guidance for entrepreneurs, considering the regional differences of a diverse country like Brazil.

The risk is inherent to free enterprise. However, there is a situation in which the lack of consensus between the different state and federal levels has unnecessarily increased the legal uncertainty resulting from different interpretations of environmental legislation, generating high costs that are paid by the Brazilian society, integrating the so-called Custo Brasil. The efficiency of a country is built by the set of processes including private initiative, public power, and society, which aim to produce wealth in a sustainable way. This concept includes the design of projects suited to environmental potential and limitations, an agile and effective licensing process that is developed under the supervision of civil society and the state. 
Preventive guidance is clearly advantageous compared to the need to resolve impacts with legal demands, which in addition to causing environmental impacts that could be predicted and avoided, determine environmental recovery costs generally higher than those required for their prevention. In addition, the judicialization of environmental processes cannot be the practice adopted for management, but on the contrary, it should be understood as an extreme measure against defaulting businessmen and representatives of public authorities who are silent. For an entrepreneur, the simple legal demand by the Public Prosecutor's Office, regardless of the later and generally late judicial decision, determines great financial losses and the complete commitment of the planning of the activity in question. In other words, even if the result is favorable, the entrepreneur has already lost.

The opening of processes resulting from different interpretations is not justified, because in these cases the State must deepen the technical debate on the topic, based on academic information with the involvement of an organized society, and determine the line of conduct to be adopted in different situations. The lack of consensus on the interpretation of environmental legislation is a difficulty that must be faced at the State level, so that the executive branch fulfills its role in adequately guiding entrepreneurs on how legislation should be interpreted, considering it is the public authority competent for this task. In this context, there is a large gap between the legal and institutional evolution, and the management practice.

The environmental issue gained importance in the Federal Constitution of 1988, with article 225, dedicated to environmental issues in an extremely advanced way and bringing the concept of sustainable development even before Rio 92. Besides that, we must also highlight the National Health Policy, promulgated by Federal Law 8.080/90, which brought about a series of aspects related to the Constitution itself, establishing the need to expand the processes of municipalization of health and environmental issues.

Between the two United Nations Conferences on Environment and Development (UNCED), which took place in Stockholm in 1972 and in Rio de Janeiro in 1992, 20 years has passed. One of the bases that influenced the debates was the document developed by the UN World Commission on Environment and 
Development, chaired by Gros Brundtland, Norway's Prime Minister. This document, entitled "Our Common Future", translated into Portuguese and published under the title "Nosso Futuro Comum", establishes the fundamental relationship between development and the environment ${ }^{11}$. It emphasizes that the integral development of any territory depends on the construction of sustainable bases, supported by the tripod of social justice, economic viability, and environmental balance. The documents negotiated at the Rio Conference were Agenda 21, and the climate and biodiversity conventions. Agenda 21 defined a series of planetary objectives, which should have been deployed by member countries, creating national agendas, which together would allow the achievement of global goals. Climate and biodiversity conventions have given rise to important global initiatives, including the known carbon credits.

When it comes to the environment and development, aspects related to urbanization, industrialization and population growth, as well as social aspects, have become relevant and directly related. The United Nations International Conference on Population and Development (ICPD), held in Cairo in 1994; the World Summit for Social Development, held in Copenhagen in 1995, and Habitat I, in Istanbul in 1996, maintained this concern, interconnecting urban and social concerns with environmental issues.

In 1997, 20 years after the Intergovernmental Conference on Environmental Education in Tbilisi, the International Conference in Thessaloniki is held in Greece, with the theme: "Education and Public Awareness for Sustainability". Also in 1997, Rio+5 takes place, whose central scope was to evaluate the five years since Rio 92, from the perspective of results achieved, evolution in resolution, and possible emergence of new issues related to climate change, for example. In this same context, Rio+10 was held in 2002 in Johannesburg, South Africa. This event drew attention to issues related to poverty, reiterating the demand for commitments and goals took on in previous conferences, which should be respected, mainly, by developed countries.

Again, there are interesting and important reflexes in Brazilian policies. In 1997, as a result of the need to regulate the articles of the 1988 Federal Constitution,

\footnotetext{
${ }^{11}$ Comissão Mundial Sobre Meio Ambiente e Desenvolvimento - CMMAD. 1987. Nosso futuro comum. Rio de Janeiro: Fundação Getulio Vargas.
} 
the National Water Resources Policy was established, instituted by Federal Law 9.433/97. In 1998, Federal Law 9.605/98 was enacted, known as the Environmental Crimes Law, and in 1999, Law 9.795/99 also was, which establishes important elements for environmental education and institutes the National Environmental Education Policy. In 2000, Federal Law 9.985/00 was enacted, which institutes the National System of Nature Conservation Units (SNUC). In 2001, Federal Law 10.257/01, known as the Cities' By-laws, establishes general guidelines for urban policy, which is a decentralized and participatory policy, in the sense that communities must participate in decisions about their areas of living, their community, neighborhood, or county.

It appears, therefore, that environmental issues are present in all these legal instruments and are conducted with an essentially democratic character, especially with regard to urban development, bringing social participation as fundamental in all decision-making processes.

A proposal and coordination of the Ministry of Cities, a bill was sent to the National Congress creating the National Basic Sanitation Policy, approved in January 2007 by Law 11.445/07. The same occurs in relation to the issue of Solid Waste. After 21 years of processing in the National Congress, involving political and economic clashes, Law 12.305/10 was enacted in August 2010, instituting the National Policy on Solid Waste.

\section{INSTITUTIONAL EVOLUTION}

In comparison, Brazil appears very close to the achievements of the central countries in terms of the construction, and legal and institutional evolution of the environmental issue. However, even with heavy institutional structures at the federal level and in most states, the excessive bureaucratization of environmental management hinders the speed and efficiency of procedures. With regard to municipalities, with the exception of a few state capitals and larger cities, few have a 
technically organized structure to assume the constitutional responsibilities of environmental management.

As previously mentioned, the Special Secretariat for the Environment was created in 1973, linked to the Ministry of the Interior. From then on, Brazilian states also started to create their environmental agencies. The National Environment Policy was established in 1981, creating SISNAMA. MMA was created in 1985, initially named Ministry of Urban Development and Environment. In 1992, this name was changed to MMA. In 1999, the Ministry expanded its activities, incorporating issues related to the Legal Amazon and water resources. The federal environmental executive agent, the Brazilian Institute of Environment and Renewable Resources (IBAMA) was created in 1989; it brings together the various agencies, until then responsible for environmental and related issues, such as the Brazilian Institute for Forestry Development (IBDF), the Superintendency of Fisheries Development (SUDEPE), the Superintendency of Rubber, as well as the Special Secretary for the Environment (SUDHEVEA). Although a single institution was created, integration between the activities of precursor bodies was not immediate. Due to the need for integration between the different government agencies and entities, the so-called forest suppression licenses are practically independent of environmental licenses until today in almost all public environmental management structures, at all levels of government.

Law 8.028/90 establishes IBAMA as the executing agency for SISNAMA. This body promoted management concentration in Brazilian environmental policy without the proper structure of the body, leading to a series of compatibility and integration problems. In the original conception of Law 6.938/81, state agencies were responsible for implementing Brazilian environmental policy. In the 1980s, licenses involving more than one state were processed in association by state agencies, accompanied by SEMA, with competence in accordance with Article 23 of the Magna Carta, to "protect the environment and combat pollution in any of its forms" (item VI) and "preserve the forests, fauna, and flora" (item VII) ${ }^{12}$.

One of the major difficulties encountered in environmental management is the lack of a clear definition of competences, which has not yet been regulated, as 
provided for in the constitution. This fact is aggravated by the uncertainty of how the concept of supplementary action should be exercised. In some states and municipalities, there are conflicts in the interpretation of legislation between environmental agencies at different levels of government, creating a great difficulty for entrepreneurs regarding the State's position on licensing processes. Given that much of the environmental legislation, especially the regulations, allows different interpretations, the lack of harmonization of the public structure brings a lot of legal uncertainty, as previously mentioned.

SISNAMA was established by Law 6.938, of August 31, 1981, regulated by Decree 99.274, of June 6, 1990, and is composed of a higher body, the Government Council; a consultative and deliberative body: CONAMA; a central organ: the MMA; an executing agency: IBAMA; and sectoral bodies: state bodies or entities that execute programs and projects, as well as inspect environmental degradation activities; and local bodies: municipal bodies or entities responsible for the control and inspection of these activities in their respective jurisdictions ${ }^{13}$. The federal, state, and municipal spheres each have their own peculiarities. At the federal level, the highest body of SISNAMA is the Government Council, an advisory body to the President of the Republic. It is an advisory body that does not exist at the state and municipal levels. The deliberative and consultative body, at the federal level, is CONAMA, whereas CONSEMAs operate at the state level (State Environmental Councils and Municipal Environment Councils). At the time of proposing this law, the local environmental bodies were the COMDEMAs (Municipal Councils for the Defense of the Environment), which demonstrated a common practice at the time, a corrective action: the environment was attacked, and therefore the councils defended. For this reason, these councils generally prospered in municipalities with more apparent environmental problems for the population. All councils have social representation, that is, the organized civil society, Non-Governmental Organizations (NGOs), and several from higher education institutions. ${ }^{14}$ The central body of SISNAMA at the federal level is the Ministry of the Environment, whereas at the state level they are the

\footnotetext{
13 Available at: https://ec.europa.eu/digital-single-market/en/news/ethics-guidelines-trustworthy-ai: http://www.mma.gov.br/port/conama/estr1.cfm/; accessed on 08/10/2012.

${ }^{14}$ Available at: http://www.ambiente.sp.gov.br/municipioverdeazul/DiretivasConselhoMunMeioAmbiente/MaterialTeoricoEstruturaConselho.pdf; accessed on $08 / 10 / 2012$.
} 
Secretaries of Environment, and at the municipal level the Municipal Secretaries of the Environment or another equivalent. The executive bodies are: IBAMA, at the federal level; environmental agencies, at the state level, such as Basic Sanitation Technology Company (CETESB), currently the Environmental Company of São Paulo State and Fundação Florestal in São Paulo; COPAM and FEAM in Minas Gerais state; FEEMA in Rio de Janeiro State; FATMA in Santa Catarina State; CRA in Bahia State; and IAP, in Paraná State, among others. At the municipal level, among the approximately 5,500 municipalities in Brazil, only roughly 500 have a specific structure to deal with environmental management. The sectoral bodies of SISNAMA are understood as the institutions that influence the environmental area, such as the Ministry of Agriculture, Health, Mines, and Energy.

Associated with institutional evolution, there are voluntary systems dictated and driven by the international market, with a strong Brazilian participation. This translates into the implementation of the ISO System, with ISO 14000 and 9000, and standards related to work safety. In Brazil there are thousands of industries certified by ISO standards, mainly with the implementation of Environmental Management Systems, ISO 14.000.

\section{SOME ASSUMPTIONS OR BASES}

Some points present in the 1988 Federal Constitution must be highlighted, which are fundamental for understanding the evolution of the Brazilian environmental system, as well as the existing correlation between public policies.

Article 182, item II, of the Constitution, for example, establishes that urban policy aims to order the full development of the city's social functions, ensuring the well-being of its inhabitants. Art. 196, which deals with health as a right of all and a duty of the state, characterizes its relation with social and economic policies, aiming at reducing the risk of diseases and other conditions, as well as universal and equal access to actions and services for its promotion. Art. 225, advocates the right to an ecologically balanced environment, characterizing it as being of common use, 
essential to a healthy quality of life, imposing on the public authorities and the community the duty to defend and preserve it. The present paper determines actions that transcend current generations in order to also guarantee a balanced environment for future generations, establishing an intergenerational characteristic for development. Therefore, paragraph 1, item VI, stands out, which deals with the need to establish environmental education. This should be understood as a transversal, non-specific theme for the formation of citizens capable of understanding the interrelations and interdependencies between the contents and ultimate purpose of the policies highlighted above, social welfare, collective health and quality of life, and environmental balance.

Another fundamental premise is the importance of environmental management, understood here as a political-administrative process under the responsibility of the constituted power, which relies on social participation to formulate, implement, and evaluate environmental policies based on the culture, reality, and potential of each region, in compliance with the principles of sustainable development, as advocated by the Report "Our Common Future". Or, in other words, as an intervention process in a given territorial base, based on general strategies established by the public power through a planning process, which materializes at the local level in the form of works and activities necessary to improve the environment. Good environmental management depends on technical studies to define priorities, joint actions between government and civil society, and the coalition of local political forces, which comes into existence as a result of this same management process.

Environmental management must be coupled with the promotion of environmental education, which must be understood as transversal to all disciplines and based on which individuals and society build values, customs, knowledge, refering to the search for a new ethos (social responsibility) also made of the notion of sustainability.

Furthermore, according to the concept of the VIII National Health Conference, held in 1986, health is the "result of the conditions of food, education, income, environmental quality, work, transportation, employment, leisure, freedom, access, 
and possession of land and access to health services" ${ }^{\prime 15}$. Therefore, factors that refer to the importance of environmental systems.

\section{AdVANCES AND Difficulties in ENVIRONMENTAL MANAGEMENT}

In view of the advances presented so far, the great difficulties encountered for the evolution in institutional, technical, legal, and operational terms are common throughout the world. However, in Brazil, the complexity of the legislation did not reflect on the structuring and training of the State, generating a situation in which the difficulties in environmental management have been a major obstacle to productive activities, incompatible with the importance of the theme. It is not a matter of asserting that environmental policy should be less restrictive, but that excessive bureaucratization of procedures does not allow it to be implemented with the necessary speed and efficiency, generating large normative uncertainties that increase legal uncertainty and define impractical deadlines for private initiative. This overview of excessive bureaucracy, complexity, and legal uncertainty contributes to deleterious misconduct in our society. The State's difficulties involve: low integration between the areas of government; obstacles to intra- and extra-governmental articulation; difficulty in defining political priorities, aind in obtaining financial resources and trained personnel; aspects associated with political and, consequently, administrative discontinuity, compromising the establishment of long-term strategic planning with actions that transcend political terms.

Regarding institutional terms, notwithstanding these difficulties, the evolution of Environmental Systems has some advances as to mechanisms and important instruments that contribute significantly to the construction of a system that transcends institutional and legal dimensions. In the case of environmental education, for example, there is a real insertion of its contents in the various levels of formal education, culminating in the unprecedented growth of specific undergraduate and graduate courses in the environmental area, even resulting in technical and scientific

15 VIII Conferência Nacional de Saúde. Relatório Final. 1986. Brasília: Ministério da Saúde, p. 04. 
advancement, which should meet the demand for trained personnel to deal with this issue in the medium and long term.

Likewise, the openness to society's participation also advances as a result of greater awareness of environmental issues, as well as institutional evolution. The creation of Environmental Councils ${ }^{16}$ existing in all Brazilian states is worth mentioning, all with deliberative power. However, in these political and participation spaces, there still exists a low effectiveness conditioned to the political culture, which is clientelist in many cases. Among other points, the Councils need qualified instruments to serve as a basis for decision making, allowing greater effectiveness of their action. The importance of implementing political instruments such as the systematization of information, ecological economic zoning, master plans, mapping of environmental information by hydrographic basins with assessment of the evolution of environmental quality, among other important management elements, is reinforced.

A large nimber of municipalities also have Municipal Environmental Councils, giving the environmental issue a local and participatory character. The municipalization of environmental management is a process that bring great benefits. However, one must clearly differentiate municipalization from "city-hall based actions". Municipalization is associated with decentralization, which requires the definition of responsibilities to municipalities that must have the necessary structure for this task to be competently performed. It is not just a matter of changing the bureaucratic decision-making process, which we call "city-hall based action" here. The great advantage of decentralization is the possibility of considering projects and their impacts in a closer way and more appropriate to local peculiarities, with easy access and inspection and, mainly, allowing public participation, that is, the population in decision-making processes. The municipal project must be the project of the society that lives there and not its submission to projects linked to quadrennial political terms.

In this context, two issues must be carefully evaluated: the clear definition of competences, and the risk of the influence of political and economic power in local

\footnotetext{
${ }^{16}$ About this aspect, consult Nunes, Fernandes and Philippi Jr (2012).
} 
decisions. What happens is that it is very difficult to define the scope of an impact without considering its intensity. Regarding competences, defining what the municipality is responsible for is essential, understanding that, in general, activities are those that have local impacts, that is, do not go beyond the limits of the municipal territory. In these cases, it is not a matter of delegation, as this would be an intrinsic municipality's responsibility. The delegation of competence implies the transfer of state or federal attributions and responsibilities to the municipality. However, what currently prevails is just the opposite: the municipality's tasks are being managed by the state, and many State's tasks, by the federal government. A clear definition of competencies is of utmost importance, because observing the overlapping of attributions is common, which in practice determines the most restrictive interpretation of the law. This fact, in addition to doubling the bureaucratic challenge, also includes the uncertainty of the contradictions between different instances of power that end up disorienting the entrepreneur about procedures to be adopted.

Any administrative body is subject to political and economic influences without legitimacy. The tax distribution legislation adopted in Brazil encourages the so-called tax war between states and municipalities, which compete for enterprises that can significantly contribute to the collection of taxes and other positive externalities, such as, for example, job creation. Thus, the criticism that says municipalization would increase illegitimate political and economic influence must be analyzed more broadly.

The central question is to understand which incentive leads mayors and governors to adopt such a position. Certainly, the form of tax distribution stands out as one of the most important points to be considered. The criteria for the distribution of the State Tax on Circulation of Goods and Services (ICMS) are: population, municipality area, agricultural production, and added value. Among these criteria, the mayor is able to influence practically only the added value, using the concession of incentives to attract productive activities. The ecological ICMS, a fifth criterion adopted in some states based on environmental aspects, loses importance over time, when the number of municipalities accredited to receive it increases, diluting initially relevant values. Thus, including sustainability criteria in the national agenda for 
rediscussing tax management is important. The theoretical proposition of the sustainable ICMS is based on the inclusion of sustainability parameters in the distribution criteria. Therefore, it would be possible to weigh the municipality area, an area with forest cover; the population with garbage and sewage collection, and treatment rates; agricultural production with the adoption of adequate land use and management; and the added value with environmental practices adopted by industries, such as effluent treatment efficiency, recycling, reuse, environmental certifications, etc.

In this way, a great emphasis would be given to the adoption of sustainable practices, in which public managers would be encouraged to not only attract companies to increase their revenues, hence characterizing a great revolution in Brazilian environmental management. It would be a way to engage the thousands of existing municipalities in the country in search of more sustainable environmental parameters.

The Water Resources Councils, implemented throughout the country, deserve to be highlighted in the environmental structuring. Nonetheless, an experience of Integrated Hydrographic Basin Committees already existed in the 1980s, such as Ceipema (Committee for Integrated Studies of the Paranapanema River) and Ceiri (Committee for Integrated Studies of the Iguazu River). These committees did not have the expected effectiveness, because they became instances without decisionmaking power, mainly due to the absence of instruments that would allow the effectiveness of their action.

The Information System has also been developed and, although still with difficulties, it is an important support for decision-making and formulation of public policies. The development of Life Condition Indicators, Sustainable Development Indicators (IDS/IBGE), Human Development Indicators (IDH/UNEP) stands out. The effort put in by São Paulo State in the construction of the São Paulo Indices of Social Responsibility and Vulnerability is highlighted, in addition to the other traditional indicators already used in the country, such as the health system indicators.

Ecological-Economic Zoning, also included in the Constitution and Law $6.938 / 81$, has been applied and has been used even in actions in the Amazon and the 
Atlantic Forest, also involving the states of Bahia and São Paulo. In the case of Bahia, the impact has been positive for the municipalization and decentralization of environmental management, with the involvement of other actors such as companies and civil society organizations.

Agenda 21 was developed at the national level in Brazil; in some cases, at the state level, as an extremely significant action plan in the pursuit of sustainable development. In addition, regional, metropolitan, and river basin Agendas 21 were developed, such as Agenda 21 for the Pirapama Basin, Pernambuco State. In the case of municipalities, it appears that more than 200 of them developed their Local Agenda 21, encouraging the participation of communities. The idea of Agenda 21 negotiated at Rio 92 was to determine goals for global strategic planning, which should be broken down into smaller scales in the form of executive plans. What happened, however, was the elaboration of procedures practically unrelated to the general vision defined in Rio, becoming a large set of socio-environmental measures defined with society.

Another point is the creation of environmental funds, with emphasis on the National Environment Fund, established by Law No. 7.797/89, as well as State and Municipal Environment Funds existing in the vast majority of the states and municipalities of the Federation. The objective of these funds cannot be the financing of environmental management activities - which must have their budget independent of extra sources of resources, especially unrelated to those originated from fines, because it would be counter-intuitive and immoral for the financing of environmental management to depend on misconduct and the consequent payment of fines. Fund resources should encourage the development of projects that aim to improve environmental quality, preferably in areas that have been affected by activities which generated such resources. However, in practice, this instrument must be improved with the implementation of measures to guarantee the effective collection of resources and guide its application with vehicles to democratize information, allowing society to monitor the investments and effectiveness of projects.

Another issue that denotes the advance of the institutionalization of the environmental issue in Brazil are the regional consortia that have been gradually implemented, such as the consortium for disposal and treatment of waste implanted 
in Porto Alegre City, Rio Grande do Sul State. The consortia associated with the Hydrographic Basin Committees in several Brazilian states must be highlighted.

Economic instruments in institutional terms also show advances, such as charging for the use of water, with application of the user-pays principle, although still in a very small number of basins; the "garbage" tax in the São Paulo City; or the ecological ICMS, applied in a pioneering way in Minas Gerais State, but which is also used in other regions of the country, such as in the states of São Paulo, Paraná and Ceará.

Basically, there are two major groups of policies for economic instruments: the one that seeks to foster sustainable activities, and the other that inhibits impacting activities, using for this purpose several mechanisms that influence the economics of the processes and production chains. The use of these economic instruments is one of the most promising aspects for the advancement of environmental policy. However, it has still been applied very timidly in our country.

Also among the economic instruments is the Payment for Environmental Services (PSA), which has been the focus of some experiences carried out in the country. In order to define payment for environmental services, for Wunder et al. ${ }^{17}$ the system must include the following criteria: the transaction must be voluntary; a welldefined environmental service or use of the environment that can ensure the provision of an environmental service must be defined; existence of at least one buyer or user of an environmental service, as well as at least one seller,or supplier of environmental service; and existence of conditionality, that is, if and only if the supplier of the environmental service ensures its supply. Thus, the PSA policies adopted in Brazil need to be adjusted to these parameters, under the risk of being confused with economic incentives for compliance with the law.

Public policies for sustainable development include those that promote environmental self-regulation in productive sectors; the adoption of environmental certification systems; encouragemente to activities that take advantage of the environmental potentials defined in zoning and land use plans; tax reduction

17 Wunder, Sven. (Coordenador); Börner, Jan. Tito, Marcos Rügnitz. Pereira, Lígia. 2009. Pagamentos por serviços ambientais: perspectivas para a Amazônia Legal / - 2ª ed., rev. - Brasília: MMA. 
sustainable products and services, such as recycled products and recycling services. Among these policies, we can mention some that offer economic advantages proportional to the implementation of environmental differentials in undertakings such as: use of recyclable products, expansion of permeable areas in cities, use of rainwater, reuse of treated sewage, reuse of gray water, adoption of energy efficient systems, encouragement to the adoption of alternatives for the collective transportation of employees and users, use of clean energy, methods of use and adequate soil management for agricultural activities, maintenance of preservation areas, in addition to those provided by law, such as ecological corridors, development of environmental education programs, adoption of reverse logistics (for products such as cell phones, electronics, batteries).

As to the legal dimension, from a constitutional point of view, environmental protection is fully contemplated and characterized both in the Federal Constitution, and in the State Constitutions and the organic laws of municipalities. Brazilian environmental legislation, which guides environmental systems, is broad and presents advances in state and municipal spheres. Brazilian law unquestionably adopts advanced legal precepts, but they are not always adapted to the national reality. Thus, they are not always effective.

The set of rules that govern our environmental policies has a number of problems, of which the following stand out: lack of definition of competences, adoption of general environmental criteria, inconsistent, confusing, and incomplete regulation.

Regarding the Budget Guidelines, environmental management systems still need to gain space. Municipalities, states, and the Union itself allocate little value to issues related to the environment. In political and management terms, there is difficulty in understanding its importance, even lacking, in some cases, economic awareness of environmental problems, as well as the correlation between environmental policies and other policies.

Notwithstanding these problems, the growth of the technical-administrative structure must be verified, with the gradual engagement of municipalities, companies, and the organized civil society. There are also increasing investments in technical and 
technological training. Despite the lack of a clear investment policy on training, there are many individual and sectoral initiatives. It is about trying to build a systemic vision that allows understanding the socioenvironmental dynamics, so that the adoption of technical and technological solutions, which are also available and provide enormous possibilities of application, can be used aiming at sustainability. The progress of this sector was increased with the emergence of laboratories qualified for environmental control, as well as technologies and proven analytical methods that can be used, allowing to create system reliability. One example, in this case, is CETESB, which has credibility not only in Brazil but throughout the world, figuring as an organization with a prominent position among the global environmental agencies.

Also regarding the technical dimension, universities and related institutions, when properly trained, encouraged, and committed, have played an extremely relevant role in the country. The existence of graduate programs has led to the creation of a large number of master's and doctoral programas within the environmental area. Likewise, a large number of undergraduate programs related to environmental issues are registered at several universities in Brazil, such as Environmental Engineering, Environmental Technology, Environmental Sciences, Environment Management, among others. More recently, the Brazilian Agency for the Improvement of Higher Education Personnel (CAPES) and the National Council for Scientific and Technological Development (CNPq) created the Environmental Sciences Area. CAPES is responsible for the accreditation, above all, and already counts with a considerable number of Courses and Graduate Programs in Environmental Sciences. In turn, CNPq is responsible for promoting research on this theme. These elements result from the incentive made by the Ministry of Science and Technology at the national level. Several states have created their own research promotion agencies, usually linked to the State Secretariat for Science and Technology, with great efforts to develop public policies with special attention to environmental issues.

Seen that, the operational dimension brings something extremely interesting in terms of mobility. The advancement of communication systems has provided the possibility of mobility to institutions in general, including those of an environmental 
nature. In terms of structure, more organizations are using modern management techniques, and, together with these techniques, the adoption of strategic planning systems is identified. From the point of view of administrative support, there is still a need for better qualification and training for employees who support the functioning of these institutions, surely indicating that this sector needs additional resources and efforts. Regarding the financial resources allocated, among those already mentioned as possible inducers of channeling resources for application, there are environmental funds, which also allow the gradual entry of resources in these funds for specific applications. In addition, the environmental licenses that were previously granted without a fixed term, just like what happened in São Paulo, started to be renewed according to their characteristics from one to three years as of 2002, thus placing the burden on those who want to carry out their activities, and no longer on the impacted society.

\section{DIRECTIONS FOR THE IMPROVEMENT OF BRAZILIAN ENVIRONMENTAL MANAGEMENT}

i) Environmental policy cannot be a partial and incomplete vision, by focusing strictly on the point of view of ecological preservation, but it must also consider the need to encourage sustainable development. This implies recognizing and valuing positive social and economic impacts, not in opposition, but considered in a balanced way with negative environmental impacts. We must also point out that well-planned projects may include characteristics that have positive environmental impacts.

ii) Environmental management must be able to differentiate enterprises with characteristics that seek the sustainability of conventional enterprises, defining differentiated administrative treatments. This is essential to encourage the adoption of more daring environmental concepts by entrepreneurs. 
iii) Defining a single environmental authority is essential: a public entity that has the role of representing the interests of society to encourage projects implementation, which present environmental, social, and economic differentials in search of the common good, allowing entrepreneurs to learn about definitions of environmental criteria and legal interpretations to be adopted for the project, which cannot be questioned by other government administrative bodies. When the different administrative instances share power, the more restrictive interpretation is worth, because for the entrepreneur, the legal questioning, regardless of the judicial sentence, makes the planning totally unfeasible, determining the non-achievement of the goals, resulting in great loss, which ultimately, are paid by society.

iv) Regulations must be built on the basis of scientific studies capable of guiding environmental management, allowing enterprises to be developed within environmental potentialities, to encourage their use by exploring the vocations of the environment and respecting their weaknesses, to define restrictions, providing, thus, the economic basis for sustainable development. Therefore, the implementation of national networks of cooperative and interdisciplinary research are suggested, which work on previously defined themes, in order to generate the information base to guide the normative work of the National Congress and other normative bodies, such as CONAMA.

v) Both environmental regulations and agencies currently focus on command and control mechanisms, presupposing precise and unambiguous regulations, which do not allow for dubious interpretations, and a well-structured state with trained personnel, capable of analyzing, deciding, guiding private initiative and public activities. For this, having an adequate structure is essential, as well as training and valuing the civil servant, which is not always properly observed by the public structure. 
vi) The legislation must be friendly to sustainable practices that encourage and differentiate enterprises, privileging those that have sustainability characteristics. The legislation must define more agile bureaucratic processes with cost efficiency, expanding legal security, support with infrastructure, and possibilities for environmental compensation in the case of use of restricted areas, thus allowing the improvement of the environmental quality of the enterprise and its surroundings.

vii) Expansion of the use of economic management instruments, which encourage sustainable activities and inhibit impacting activities. Possibility of adjusting the tax distribution laws to induce city halls and governments to sustainable development.

viii) One of the most priority tasks yet to be carried out by Brazilian environmental policy is state greening, both in its executive functions, in the implementation of infrastructure, and in its role of promoting development in programs of economic incentive to sustainable activities. It is not uncommon to see conflicts between environmental agencies and other state's organizations. In addition, procedural licensing processes are often not enforced with the same rigor required for private initiative. State activities have a major influence on development. Therefore, its redirection to promote policies aimed at sustainability is one of the most urgent and important tasks. For state greening, each ministry or secretariat must have their own environmental agenda, with defined goals, deadlines, resources, and responsibilities. This is the moment to define the extent and importance of public environmental policy, which the State proposes to implement. The management of the set of sectoral agendas is the responsibility of the MMA/State and Municipal Environment Departments, with wide dissemination of the programs execution.

ix) Environmental Impact Assessment procedures have been carried out in Brazil in a more effective way since 1986, with the implementation of Conama Resolution 001/86. Both its elaboration and the political 
feasibility of its implementation were the result of a political articulation carried out by ABEMA. However, it turns out that the Environmental Impact Study (EIA) and Environmental Impact Report (RIMA) instruments, which have been adopted since then, are appropriate for evaluating projects, but not for broader public policies. Besides that, the Neighborhood Impact Study (EIV) and Neighborhood Impact Report (RIVI) instituted by the City's By-laws, complement environmental control at the local level. The environmental analysis of a hydroelectric power plant, for example, cannot consider the energy matrix in which it is inserted, therefore, the conclusions lose the quality of a broader perspective. In this specific example, the most important moment for limiting the impacts of hydroelectricity occurs in the distribution of the falls, in which there is no legal provision to justify the participation of environmental agencies.

This implies that certain strategic works are defined politically without prior environmental analysis in a broader context, and that environmental licensing, in these cases, does not have the function of approving or not the project, but rather of defining the mitigating and compensatory measures that will be required for its viability. The strategic locational definition for the implantation of infrastructure (such as ports, roads) must be made based on comparative environmental criteria. Likewise, the definition of technological typology (power generation by thermoelectric, hydroelectric, wind power plants, etc.), should define the State's position in relation to the execution of strategic undertakings. The "fine tuning" with the assessment of specific impacts of the project adaptations, in addition to the mitigating and compensatory measures, would continue as a function of EIA, after the definition of the execution or not of the work, based on environmental criteria in the stage of strategic environmental assessment.

The most appropriate management instrument for the definition of more comprehensive policies is the assessment of strategic environmental impact, which must naturally have a procedure quite different from the model adopted for the 
EIA/RIMA. The participation of the environmental area occurs in the definition of the work scope (possibly in the elaboration of part of the study) and the analysis must be made in a higher instance, which considers the positive and negative impacts of the defined policy, with the objective of improving its general conception.

\section{FinAl CONSIDERATions}

All the aspects mentioned and discussed in the present paper allow us to verify in the study period, 2014, the evolution of the Brazilian system and the pace at which it has been occurring, including prospecting, for the purposes of decision making, in which investments should be made. Considering the federal sphere, the institutional and legal dimensions seem to have evolved quite significantly and, in theory, they could mean that until 2014, Brazil prioritized the environmental dimension in its development process. However, the technical dimension, related to environmental issues, is only moderately implemented, whereas the operational dimension is extremely fragile.

"That is, considerable institutional apparatus and legal framework have been created, but the right conditions for them to work with the 960 necessary results have not." (Fernandes \& Sant'Anna, 2007, p. 5)

On average, the situation is quite similar at the state level, considering that in some states the national average is exceeded, and in others the system is still very precarious. The same occurs in the municipal sphere, whose greatest difficulties are also of a technical and operational nature.

Environmental management is one of the political activities that opens a privileged space for public participation, encouraged by the principles of democratization of information, such as the publication of licenses, councils, public hearings, in addition to the instruments that were provided for by Law 6.938, but which have not been materialized yet, such as the environmental quality report (RQMA). 
Thus, when society wants to take a position on a project, the open door for manifestation is public hearings for the presentation of RIMA.

Given this scenario, some efforts seem to be imperative for an effective progress to be made regarding the real insertion of the environmental dimension in the country's development process. As to river basins, as well as in metropolitan regions, these efforts must be expanded in the search for a new model or new institutional modality in the face of challenges. The construction and implementation of the Agenda 2030 at the national and local levels may mean the expansion of democratic spaces and a way of building a common agenda for sustainable development in the country. A more expressive development of environmental information systems is needed, creating specific indicators that, in fact, support decision making by the State, companies and civil society itself, regarding the environmental issue. With regard to environmental education, efforts should also be made, mainly to think about the transversality of environmental education, not as a discipline, but as new knowledge, a new context that must integrate all existing disciplines. In this sense, the development of teaching methods and materials must incorporate the results of research that has been carried out on the theme over the past few years. Training environmental agents and leaders will also depend on this environmental education, which is why it is absolutely necessary when we consider the need to have leaders and agents who have knowledge of what they are participating, considering the democratic processes and the entire universe of socioenvironmental problems. Thus, participatory mechanisms must be resumed and improved in Brazil, so as to use not only public hearings and conferences as instruments, in which society can participate, but as a way to legitimize decisions and constant participatory processes, with the creation of spaces, such as Councils and other forms of association in which different positions can be debated to improve society's living conditions.

The basis of this whole process, which uses environment systems, environmental education, and the participation of civil society as an instrument, must be a new paradigm to be reached, the paradigm of sustainability, with a transforming vision of contemporary society's values, which presupposes the need to understand 
that we have to migrate from an excessive valuation of quantity to the valuation of quality. According to Gorz ${ }^{18}$, that means to understand, in addition to the notions of plus $(+)$ and minus $(-)$, the notion of sufficient, overcoming polarizations and dichotomies, starting from the concept of independence, widely adopted in the construction of institutions to reach the concept of interdependence between projects, programs, and institutional relations. Besides that, replacing the notion of competition with the notion of cooperation is also needed, as well as balancing the primacy of technical and economic efficiency with concern for justice and equity; moving the axis, which today rests on the imposition of system conveniences, to the self-development of the people who are members of these systems; replacing authoritarianism and dogmatism veiled or declared, and impregnated in actions, with participation and empowerment; giving up the security of uniformity and centralization in favor of diversification and pluralism; replacing the concept of work, as something inevitable and an often unpleasant obligation, with a concept of work as a self-fulfillment and ideal of life, at the same time that it must be understood once more not as an end but as a means, an important part of development processes.

\section{REFERENCES}

VIII Conferência Nacional de Saúde. Relatório Final. 1986. Brasília: Ministério da Saúde. Associação Brasileira de Entidades Estaduais de Meio Ambiente, Abema, 2011. O que é Abema. Accessed on: Jun. 12, 2011. Available at: http://www.abema.org.br/site/pt$\mathrm{br} / \mathrm{abema}$

Carson, Rachel. 1962. Silent Spring. Boston: Houghton Mifflin Co.

Comissão Mundial Sobre Meio Ambiente e Desenvolvimento - CMMAD. 1987. Nosso futuro comum. Rio de Janeiro: Fundação Getulio Vargas.

Gorz, André. 2003. Metamorfoses do trabalho: crítica da razão econômica. São Paulo: Annablume.

18 Gorz, André. 2003. Metamorfoses do trabalho: crítica da razão econômica. São Paulo: Annablume. 
Fernandes, V., \& Sant'Anna, F. (2007). A INSERÇÃO DA DIMENSÃO AMBIENTAL NAS INDÚSTRIAS CATARINENSES E A SUA CORRELAÇÃO COM AS POLÍTICAS PÚBLICAS. Brazilian Journal of Environmental Sciences (Online), (06), 4-8. Retrieved from http://rbciamb.com.br/index.php/Publicacoes_RBCIAMB/article/view/450

Meadows, Donella. Randers, Jorgen. Meadows, Dennis. 2007. "Limites do Crescimento: a atualização de 30 anos". Rio de Janeiro: Qualitymark.

Nunes, M., Philippi Jr, A., \& Fernandes, V. (2012). Gestão Ambiental Municipal: objetivos, instrumentos e agentes. Brazilian Journal of Environmental Sciences (Online), (23), 66-72. $\quad$ Retrieved from http://rbciamb.com.br/index.php/Publicacoes_RBCIAMB/article/view/333

Philippi Jr, Arlindo. Andreoli, Cleverson Vitório. Bruna, Gilda Collet. Fernandes, Valdir. 2014. Histórico e Evolução do Sistema de Gestão Ambiental no Brasil. In: Arlindo Philippi Jr; Marcelo de Andrade Roméro; Gilda Collet Bruna. (Org.). Curso de Gestão Ambiental. 2ed. Barueri: Manole, v. 1, p. 19-52.

São Paulo (Estado). Secretaria do Meio Ambiente - Brasil'92 Perfil Ambiental e Estratégias. 1992. São Paulo, Secretaria do Meio Ambiente, 218p.

Wunder, Sven. (Coordenador); Börner, Jan. Tito, Marcos Rügnitz. Pereira, Lígia. 2009. Pagamentos por serviços ambientais: perspectivas para a Amazônia Legal / - $2^{\mathrm{a}}$ ed., rev. - Brasília: MMA.

Conforme Better Regulation Executive all legislation is amended from time to time. (...) It is extremely difficulto to keep track of themost up to date version of legislation. Accessed on: $\quad$ Sep. 26, 2012. Available at: http://www.betterregulation.gov.uk/ideas/viewidea.cfm?proposalid=d4267e2ad07a4 b5b9b0fba354be131b9\&tunnel=bl

Discussão do Marco Regulatório para o Saneamento Básico. Accessed on: Aug. 10, 2012. Available at: http://www.abdib.org.br/arquivos_comite/11h15m_julio_lopes.pdf

Vide Accessed on: Aug. 10, 2012. Available at: http://www.ibama.gov.br/licenciamento-ambiental/processo-de-licenciamento

Vide Suely Mara Vaz Guimarães de Araújo, março 2005. Accessed on: Aug. 10, 2012. Available at: http://bd.camara.gov.br/bd/bitstream/handle/bdcamara/1022/distribuicao_comp etencias_vaz.pdf?sequence $=1$

Vide. Accessed on: Aug. 10, 2012. Available at: http://www.mma.gov.br/port/conama/estr1.cfm/.

http://www.ambiente.sp.gov.br/municipioverdeazul/DiretivasConselhoMunMeioAm bi-ente/MaterialTeoricoEstruturaConselho.pdf. Accessed on: Aug. 10, 2012. 


\title{
Historia y Evolución del Sistema de Gestión Ambiental en Brasil
}

\begin{abstract}
RESUMEN
La idea de desarrollo sostenible surge primero como un movimiento sociopolítico, a partir de una serie de interrogantes y preocupaciones que han surgido a nivel internacional, relacionadas con la contaminación de los ambientes naturales y seres humanos, resultado de las actividades industriales. A partir de estas inquietudes, una serie de hechos y movimientos provocaron cambios significativos en las políticas internacionales y nacionales, que llevaron a la construcción de un marco legal y un aparato institucional significativo, nunca visto en ningún otro tema. El establecimiento de sistemas de gestión ambiental en la mayoría de los países fue un reflejo directo de una agenda internacional lanzada durante la Conferencia de Estocolmo, en 1972, que continuó con varias otras conferencias y protocolos, como Río-92, Río + 20, Protocolo de Kioto, París Acuerdo, entre otros, que ha consolidado una agenda ambiental internacional durante los últimos 50 años. En Brasil, este proceso generó reflejos directos con la construcción de un importante marco legal y aparato institucional. En este artículo describimos este proceso, una parte importante de la historia ambiental brasileña y mundial hasta 2014.
\end{abstract}

Palabra claves: Desarrollo Sostenible; Políticas Públicas Ambientales; Sistema Ambiental Brasileño; Historia Ambiental.

Recibido: 05/02/2021

Aprobado: 21/04/2021 